\title{
The Andean Condor as bird, authority, and devil: an empirical assessment of the biocultural keystone species concept in the high Andes of Chile
}

\author{
Andrés Jacques-Coper $^{1,2}$, Guillermo Cubillos ${ }^{3}$ and José Tomás Ibarra $^{4,5,6}$
}

\begin{abstract}
Biocultural keystone species have been suggested for different societies, but there has been little empirical evaluation of their role in the face of rapid socio-environmental changes. The Aymara people of northern Chile have experienced historical and contemporary processes that have modified their culture and relationship with nature. The Andean Condor (Vultur gryphus) has previously been proposed as a biocultural keystone species for traditional Andean societies. We evaluate the validity of this assertion in the light of the traditional ecological knowledge (TEK) of today's Aymara from the high Andes of northern Chile. A three-month ethnographic study was conducted in the Putre municipal district, including semistructured interviews, focus groups, and surveys of the district's Aymara inhabitants. Our results indicate a nonarticulated set of information that can be identified as knowledge about the Andean Condor but is patchy and resembles relics, rather than an ongoing body of TEK that includes daily practices, social institutions, and a worldview shaped by the putative biocultural keystone species. Chileanization, migration, and the integration of evangelical religions into the area's Catholic-Andean setting were identified as three processes that have deeply affected the transmission of TEK and the Aymara-condor relationship, with new generations living in socio-environmental contexts different from those of their ancestors. We suggest that, today, the condor can hardly be considered a biocultural keystone species for the Aymara people of northern Chile. Our study highlights that the role of putative biocultural keystone species is dependent on the vagaries of historical and contemporary socio-environmental processes occurring in the Andes and elsewhere.
\end{abstract}

Key Words: biocultural diversity; biocultural memory; Chileanization; rural-urban migration; Pentecostalism; traditional ecological knowledge

\section{INTRODUCTION}

The evidence of a space-time overlap and the close links that exist between biodiversity and cultural diversity (Maffi 2005, Gorenflo et al. 2012) have led research efforts and conservation management to focus on biocultural diversity (Posey 1999, Oviedo et al. 2000). The maintenance of a biocultural relationship depends on the intergenerational transmission of knowledge. This set of information is referred to as traditional ecological knowledge (TEK) and is a cumulative body of knowledge (corpus), practices (praxis), and beliefs (kosmos) that is generated, transmitted, and modified in response to socio-environmental changes (Berkes et al. 2000, Toledo and Barrera-Bassols 2008). Multiple nested and interrelated levels of TEK include (a) empirical situated knowledge of animals, plants, and their habitats, e.g., information on the identification, biology, and distribution of certain species; (b) a set of practices, e.g., tools and techniques, for managing species or habitats, together with the social institutions, e.g., rules-in-use, norms, and codes, associated with these practices; and (c) the worldviews, e.g., religion and ethics, that shape the lenses through which a species is perceived and that also assign meaning to observations of the species (Orlove and Brush 1996, Berkes 2018).

Time is needed for TEK to evolve organically as people find new ways of responding to new challenges and changing socioenvironmental circumstances (Maffi and Dilts 2014). This is a process that involves cognitive and affective learning as individuals refine their TEK through accumulated historical, socially shared, and individual experiences. Recent studies have suggested that "biocultural memory," defined as the experiences above the individual level that have been accumulated and handed down through generations, function as a mnemonic reservoir that allows human societies to adapt to a complex world that is constantly changing (Nazarea 2006, Toledo and Barrera-Bassols 2008, Barthel et al. 2010). Two key components of biocultural memory are the "internal sources of memory," or the living or working memory present within the community, and the "external sources of memory," which are dynamic repositories outside the traumatized sphere (Nazarea 2006). Adaptation of TEK to socioenvironmental changes is, thus, the result of a combination of synergic operators that are embedded in the social fabric (Berkes et al. 2000).

The importance that a species has for a particular society is reflected in its biocultural significance in cultural domains, e.g., religion, myth, art, ritual, politics, science, technology, economy, medicine, language, etc. (Ibarra et al. 2012). This importance is related to the multiple uses of the species and the way in which it is known and perceived. In this nonstatic relationship, some species have more biocultural importance than others and stand out for their prominent role in structuring the society with respect to the environment. Such species are recognized as "biocultural keystone species" and are those that have a central role, both ecologically and culturally, in the regions they inhabit (Ibarra et al. 2012). This concept has its origin in the initial definition of "ecological keystone species" in the natural sciences (Paine 1969)

\footnotetext{
${ }^{1}$ Proyecto de Conservación del Cóndor Andino, Zoológico Nacional de Chile, Chile, ${ }^{2}$ The Peregrine Fund, Boise, ID, USA, ${ }^{3}$ Sección Educación para la Conservación. Proyecto de Conservación del Cóndor Andino, Zoológico Nacional del Parque Metropolitano de Santiago, Chile, ${ }^{4}$ ECOS (Ecology-Complexity-Society) Laboratory, Center for Local Development (CEDEL), Villarrica Campus, Pontificia Universidad Católica de Chile (PUC), ${ }^{5}$ Center for Intercultural and Indigenous Research (CIIR), Pontificia Universidad Católica de Chile, ${ }^{6}$ Center for the Socioeconomic Impact of Environmental Policies (CESIEP), Pontificia Universidad Católica de Chile
} 
and, subsequently, in its metaphorization in the social sciences through the concepts of "cultural keystone species" (Garibaldi and Turner 2004) and "ethno-biological keystone species" (Ellen 2006). For their part, Platten and Henfrey (2009:493) assert that cultural keystone species are "system elements with crucial nonredundant functions in maintaining any particular level of structural complexity." Garibaldi and Turner (2004) proposed a quantitative approach to identifying a biocultural keystone species, which involves comparing the values of certain variables, assigned by the members of a society, to the particular species. It is predicted that the loss of biocultural keystone species or variations in their availability can drastically affect the human communities that relate to them (Garibaldi and Turner 2004, Ellen 2006). Previous studies have explored how historical, political, and ecological forces have irretrievably reduced populations of biocultural keystone species and, as a consequence, affected local livelihoods (Costanza et al. 2017, Uprety et al. 2017). However, little is known about how these socio-environmental factors can divert the interest of an indigenous people away from a species previously considered a biocultural keystone species.

The Andean Condor (Vultur gryphus) is found in the Andes from Venezuela in the north to the Cape Horn Archipelago in the south of Chile as well as in coastal areas of Peru, Chile, and Argentina (Fjeldså and Krabbe 1990, del Hoyo et al. 1994, Ferguson-Lees and Christie 2001). In Chile, it is classified as vulnerable in the north and center of the country and as rare in the south, except for the far south where it is common (SAG 2015). In the very north of its distribution in South America, the condor is critically endangered (Rodríguez and Rojas-Suárez 2008), with only sporadic sightings in Venezuela (Lambertucci 2007). Generally speaking, the population of condors in South America is shrinking, with the principal threats including habitat degradation, illegal hunting, poisoning, and lack of food (BirdLife International 2017). Besides playing key ecological roles in terrestrial communities (Lambertucci et al. 2009, Elbroch and Wittmer 2013), the condor has been embedded in the biocultural fabric of Andean societies since time immemorial. It is part of the worldview of the pre-Columbian Andean societies of what is now Chile, and most of today's nation states along the Andes have established it as an identitarian icon (Ibarra et al. 2012). Archaeology, ethnohistory, music, poetry, and literature all testify to its symbolic significance. Some symbolically predominant representations can be found in most of the cultural domains of the societies that have inhabited the Andes as is described in, for example, Palma (1983), Gordillo (2000), Rozzi et al. (2003), Montealegre (2007), Vargas-Clavijo and Costa Neto (2008), and Millones and Mayer (2012). This led Ibarra et al. (2012) to suggest that the Andean Condor may be considered a biocultural keystone species for many traditional societies of South America.

The Aymara people is the main pre-Columbian culture of the Andean territories where the borders of Peru, Bolivia, and Chile now meet. Its ethnozoology gives a privileged position to some animal species and is largely shared by other earlier and contemporary Andean cultures such as those of the Quechua, Tiwanaku, and Inca (Palma 1983). Archaeological and early ethnographic research in northern Chile described the prominent roles played by the condor for the Aymara people. In Isluga in northern Chile's Tarapacá Region, the condor was reported to be regarded as one of the sacred animals that mediate the relationship between agriculture and the spirits of the mountains known as mallkus (Grebe 1983, 1984, 1989). The mallku concept can be understood in at least two ways: as an authority of the community and as spirit/divinity. According to Grebe (1989), Mallku kunturi identified the condor as the bird with the greatest authority among its peers and indicated its sacred nature (the name condor comes from the Aymara and Quechua word kuntur). Grebe (1989) described how, together with the eagle, the condor connected the three worlds of the Aymara worldview through its flight. Magaña (2006) presented the condor as a celestial constellation in the Upper Loa area (Antofagasta Region, Chile). Valenzuela et al. (2015) described the archaeological record compiled in the Atacama Desert of Chile's Arica y Parinacota Region, where representations of the condor are found in all the ecozones of the lowlands, despite being mainly a bird of the high Andes. Castro and Rottmann (2016) reported that parts of the condor's body were used in traditional medicine and its meat is supposed to slow aging (Castro 1986).

Over the past century, the Aymara have experienced socioenvironmental processes that have influenced their identity and relationship with nature. These processes were related principally to rural-urban and mountain-coast migration (Grebe 1986, Gundermann and González 2008, Ohrens et al. 2016), Pentecostalism, and Chileanization (Choque 2012). These processes have reportedly resulted in a dialectic of negation in which the Aymara seek to marginalize themselves to avoid discrimination and, at the same time, maintain their identity (González 1999). This could also affect the transmission of TEK because the new generations live in socio-environmental contexts different from those of their ancestors. The literature has described an unpromising situation for the survival of the Aymara identity as regards the continuity of traditional practices (Guerrero 1984, Van Kessel 1985, Grebe 1986, González 1999, Quiroz 2012, Díaz and Tapia 2013).

The research presented here assesses the current relevance of viewing the condor as a biocultural keystone species for the Aymara people from the high Andes of northern Chile. For this, we implemented an ethnographic study that has been little used for explicitly assessing the role of biocultural keystone species in traditional societies. Ethnography can provide in-depth insights into rational and emotional connection with species and landscapes, along with the day-to-day expression of TEK. We hypothesized that the current relationship between the Andean Condor and the Aymara people of the high Andes of northern Chile reflects marked historical and contemporary socioenvironmental changes in the Aymara territory. The study demonstrates the usefulness of ethnographic methods for empirical and in-depth evaluation of the relevance of the concept of biocultural keystone species in traditional societies.

\section{METHODS}

\section{Study area and ethnographic context}

The Arica y Parinacota Region marks the far north of Chile, bordering with Peru to the north and Bolivia to the east. It includes coastal environments, valleys, absolute desert, high Andean wetlands, salt flats, and the Andes Mountains (Hernández et al. 2014). In altitude, it varies from the coast to 
volcanoes that reach over 6000 meters above sea level (m a.s.1.). Administratively, the region is divided into two provinces, each of which comprises two municipal districts. The Parinacota Province includes the Andes foothills, the high Andean plateau, and the mountains themselves. The Putre municipal district is located in the southern part of the Parinacota Province and has an area of some $6000 \mathrm{~km}^{2}$ of which $60 \%$ corresponds to three State protected areas: the Lauca National Park, the Salar de Surire Natural Monument, and the Las Vicuñas National Reserve. The management plan of the latter (the main area studied) seeks to harmonize traditional agricultural activities with the conservation of nature in a social context of "deterioration of the traditional culture" (CONAF 1998).

Migration in search of better economic conditions has reduced the population, principally the case of the Andean plateau where settlements now often have no more than 10 inhabitants. The town of Putre, located in the municipal district of the same name, has an estimated 2765 inhabitants (2017 Census). The population is concentrated mainly at an altitude between 3600 and $4200 \mathrm{~m}$ a.s. 1. where climatic conditions allow small-scale agriculture and livestock production. For this study, fieldwork was conducted in the foothill settlements of Zapahuira, Murmuntani, Chapiquiña, Belén, Tignamar, and Timalchaca and, in the case of the Andean plateau (> $4000 \mathrm{~m}$ a.s.1.), in the Guallatire and Surire sectors. In these areas, remaining Aymara people practice small-scale agriculture in the form of crop terraces and domestic camelid husbandry.

\section{Fieldwork}

The study used principally ethnographic techniques and involved three months of residence in Putre, specifically at the International Center for Andean Studies (INCAS) of the Faculty of Veterinary and Livestock Sciences of the University of Chile. The first stage of the work consisted in obtaining free prior informed consent, achieving insertion into the Putre community, identifying its social groups, and getting to know local authorities. This permitted identification of the main social instances where perceptions of the Andean Condor and relationship with it could potentially be explored. With the help of the local authorities, we identified different socio-cultural groups in the study area according to categories such as age (e.g., elder: $>60$ years old, adult: 20-59 years old, children: 7-14 years old), religion (e.g., Catholic, Evangelical), origin (e.g., Chilean, foreigner), and main activity (e.g., farmer, livestock herder).

Based on the conversations that took place during the first stage, we refined the thematic questionnaire used in further semistructured interviews and as a thematic guide for the ethnographic study (Bernard 2011). The questions used during semistructured interviews and during focus groups included the following topics: (1) interviewees' socio-demographic characteristics (sex, age, ethnicity, place of residence); (2) identification, biology, and distribution of the condor, including its role in some cultural domains; (3) social importance of the condor and social institutions associated with it; (4) the perceived value of condor conservation; (5) mechanisms of knowledge transmission. We interviewed authorities and other people identified as key participants during the first stage, e.g., Q'olliris or traditional Aymara doctors, with a total of 64 interviewees. Thirty-four
(53.1\%) of the participants were adults, $15(23.4 \%)$ were elders, and 15 were children. Two environmental education workshops were held at Putre's Granaderos Secondary School, with one focus group conducted in each. Focus group interviews $(\mathrm{N}=39$ persons $)$ were conducted with the Putre Senior Citizens Group (15 people), the $1^{\text {st }}$ Timalchaca Traditional Dancing Company (10), Small Farmers of Chapiquiña (5), Small Farmers of Putre (6), and Q'olliris of the Putre Family Health Center (3). The Senior Citizens Group and the Q'olliris were the only focus group interviews that were scheduled beforehand and the topic presented in a formal setting. During the focus groups, we encouraged and facilitated a group conversation about the condor and the socio-environmental changes that had occurred in the territory.

Because most interviews were often long conversations that took place during working activities, the semistructured questionnaire was always completed with each participant, but questions were not always asked in the same order. The information was compiled mainly in the form of field notes that were systematized and tabulated to identify points of consensus and dissent; we then carried out thematic analyses (Bernard 2011). Because this was an ethnographic study, situational analytical annotations were included in field notebooks, indicating the context, the emotional situation, and the linking of themes. We also analyzed individual or group discourses (Newing 2011); the latter were obtained during the focus groups. The analytical annotations of the discursive context meant that not only answers were recorded but also the hesitations and insecurities that, along with other elements, are not necessarily expressed verbally (Bernard 2011).

To understand spatial knowledge about the distribution and ecology of condors, a map of the area was used as a backup in semistructured interviews, although only when the interviewee felt comfortable with it. Spatial references were systematized to identify possible patterns of spatial knowledge about the areas occupied by condors or relevant cultural sites associated with the species. All spatial references were tabulated and grouped according to their precision, generating information on different spatial scales. The most accurate references, i.e., indicating certainty about the delimitation of the event in space, which were relatively small in number (because the map was not always used), were identified as points on the map while the vast majority of references, which were vaguer in that they referred to a large area, were mapped as polygons. For this mapping, we used ArcMap 10.3.1, based on a digital elevation model created with contour lines every 50 meters. The political-administrative division of the region, its natural protected areas, road and water networks, toponymy, and populated sites were then superimposed on this map.

\section{RESULTS AND DISCUSSION}

TEK about the Andean Condor: survival of the mallku?

Our ethnographic research reveals a nonarticulated set of information that can be identified as knowledge about the Andean Condor but is patchy and resembles relics, rather than an ongoing complex of TEK. Information about the species as such (identification, biology, and distribution) was more abundant and a matter of greater agreement than articulated biocultural 
memory of practices, social institutions, and a worldview associated with this species. Emotions were expressed at the personal level, based on what the condor's presence and absence evoke, but the transmission of beliefs and social practices associated with the condor were scarce. The local image of the condor is currently a patchwork of mostly unconnected pieces but, from the social group, it was possible to build a picture of what it has represented as an Aymara symbol. The mallku (the authority or divinity-bird) fades but admiration for the condor persists.

\section{Notions about condor identification, biology, and distribution}

The main consensus ideas found were (1) the condor is a longlived species, which was often related to its lifestyle as represented by its calm and constant gliding and to its habitat in the high mountains, away from the fast dynamics of the world. (2) Reference was made to its long reproductive cycle, with an egg every two or three years. (3) For some older people, the condor's ruff is unquestionably a symbol of it being the mallku, denoting hierarchy and elegance. There is consensus that this is the case only of the adult male, reinforcing its power over its mate and in the flock. (4) The condor's sexual dimorphism in the color of the iris was not mentioned, but the color of its tears as being different in each eye was mentioned. (5) In its relations with other species, the condor was described as a scavenger and an occasional hunter of young livestock or dying animals. In myths and fables, it interacts with fauna as an exemplary leader, a remnant of the mallku concept (see details below).

The inhabitants of Andes foothills could not, in general, exactly identify the places where condors live. Instead, they referred to relatively extensive sectors such as the Andean plateau, particularly the area around Guallatire. They also reported that condors move down to the foothills during the day, particularly to Socoroma and Putre (Fig. 1). Specific places were mentioned principally by elderly men, but did not follow a general pattern. Notions about condor ecology and distribution were a mixture of what has been transmitted by others and the knowledge acquired through personal experience.

Inhabitants of the Andean plateau were more precise in identifying places, naming gorges close to their homes and even reporting nests of condors. Among them, there were three recurrent ideas: (1) condors live in the mountains and on volcanoes because they are known for their resilience to harsh climatic conditions; (2) condors live in mysterious and somber places, far from the world of people, which are difficult to access; (3) condors are more common on the Andean plateau than in the foothills, which are regularly distinguished as adjacent but different landscapes, each with their own fauna. Condors move through both landscapes but belong principally to the plateau.

Local residents generally indicated that condors were most common during the period of livestock reproduction. Older people recalled constant encounters with condors during their youth when they could be a danger. Among adults and the elderly, there is consensus that the 1970 s and 1980 s marked an inflection point in the condor population. Its decline was attributed principally to variation in the ungulate population (main carrion source) and, possibly, climate change.

\section{The condor in some cultural domains}

\section{Legends and fables}

In these stories, the condor interacts with other animals, mainly the Darwin's Rhea (Rhea pennata), fox (Lycalopex sp.), and Oasis Hummingbird (Rhodopis vesper), and stands out for its noble personality. With regard to human beings, the condor is represented as a threat, particularly to young women, transmitting the dangers of being out in the countryside alone. These stories also reflect the idea that, in olden times, animals and people could be the same beings who changed form. In these cases, the condor appears as a well-dressed man with power.

Fig. 1. Study area in the Andes of northern Chile. Local residents generally identified large areas of the foothills where condors (Vultur gryphus) can be seen and possible places where they live higher up in the mountains. The areas most frequently mentioned were in the vicinity of Putre and Socoroma and the Guallatire Volcano, followed by the Visviri mountains and the Surire salt flat. Condors are believed to move across regions, from their source in the mountains down to the foothills through which they merely pass. Arrows: indicate the direction, described by interviewees, of the movement of condors during the day, from their resting to feeding places. Orange areas: resting and roosting places; red areas: daytime feeding places; yellow area: possible destination without personal sightings. The star indicates the location of the Condor Stone.

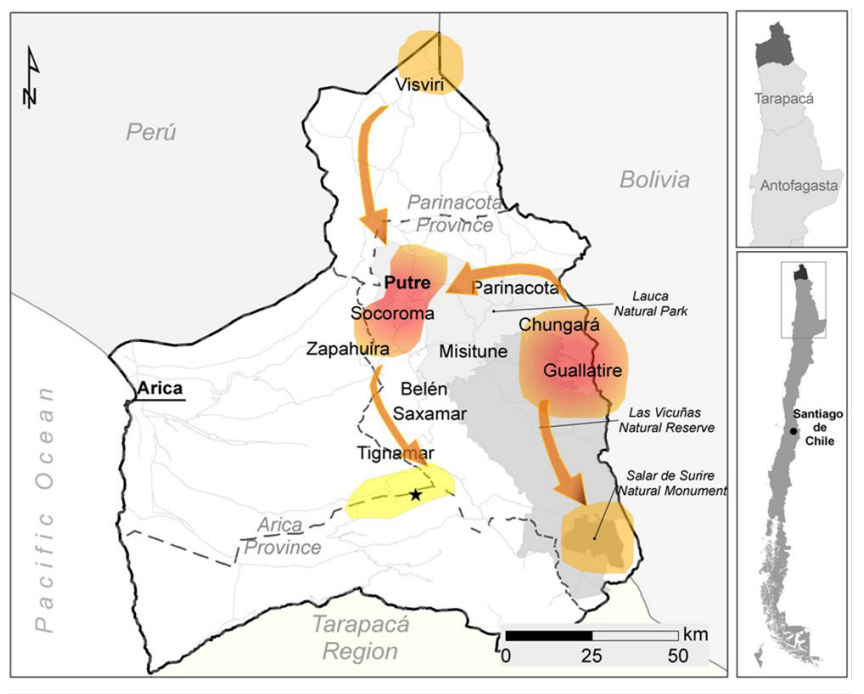

The condor is believed to have one white and one red eye or, in a variant, tears from one eye are white and, from the other, red or blood. In the latter case, this is explained as a sign of the great pain the condor can feel and transmit, which is also represented by its solitary flight.

\section{Murals}

In Putre, Belén, and Tignamar, there are a series of murals depicting stories from local oral tradition and representing the Andean landscape with its flora and fauna. Similar murals can also be seen in shops related to tourism and services. The condor appears mostly as a symbolic icon that represents the Andean landscape and culture. An important part of the murals are the 
result of projects external to the community, but some were designed with the participation of local inhabitants. In this case, artists from the coastal city of Arica, some with an Aymara origin, act as an "external source of biocultural memory" (sensu Nazarea 2006) that reminds people living in the mountains and in the high Andean plateau about the ancestral role of the condor in local culture. This dynamic is also seen in other artistic expressions as, for example, in dance when, at carnival time, Arica represents the Andean imaginary, creating expectations about what ought to happen in the traditional rural world.

\section{Ritual}

In the study area, the only manifestation of occupation of space in displaying the image of the condor that has persisted as a tradition involves a natural sculpture, the Condor Stone. Inhabitants of all the Parinacota Province refer to it, but only those from nearby towns know its location and name. The Quebrada del Cóndor (Condor Ravine) gets its name from this sculpture and is mistakenly believed to be a place for sighting condors. The shape of the rock, which is the result of erosion by the wind and water, resembles a condor opening its semiextended wings (Fig. 2A). Its head is supported by a long curved neck that emerges from a rock that serves as a table for offerings. A white scarf has been placed around its neck, imitating the bird's ruff (Fig. 2B). In a chuspa, a traditional woven bag, surrounded by colored streamers, there are a number of banknotes and, at the bottom, coca leaves. The offerings are mostly coins, some Chilean and some foreign, that are no longer legal tender and have been intentionally saved for this purpose because they bear the image of a condor (Fig. 2C). The ritual consists of challar (to make an offering with alcohol and carnival elements) to the sculpture on the eve of the feast of the Virgin of the Remedies of Timalchaca (8 December). Participants in this ritual indicated that they did so only to follow the tradition. It does not take them back to the link their ancestors may have had with the condor, but relates them directly to their ancestors, without reviving the ideas surrounding the condor, and certainly does not link them to the species itself. They report that it is the idea of their ancestors, not the condor, that is celebrated. In other words, the ritual is a manifestation of a tradition that may have had meaning related to the species, but no longer does.

\section{Customs and medicine}

The sighting of a condor was related to luck and, for it to be good luck, the condor must be greeted with the hand or by taking off one's hat. For part of the population, this may indicate that a pleasant unexpected event will happen, that a process will reach a good conclusion, or that it is time to make an important decision. For others, however, it is a sign of bad luck and an omen that someone will die.

There are few references to use of the condor's body. It is said that, in the past, it was common to use the dried meat for medicinal purposes, although this was restricted to specific situations because of potential negative effects. In the past, it was consumed mainly to slow aging, a benefit that, however, had a high cost because it also implied a long and painful agony. Condor meat was also believed to have regenerative power. In addition, ash from the burning of condor feathers was reported to have been used to cure illnesses and stop bleeding from the nose or mouth, while the smoke was inhaled in cleansing ceremonies. Expressions such as those described by Castro (1986) and Castro and
Rottmann (2016), involving the medicinal use of condor feathers and meat, were mentioned by local inhabitants. Although these practices are no longer in use, Aymara inhabitants of the Andean plateau report having witnessed them, mainly during their childhood.

Fig. 2. Condor Stone, Tignamar, northern Chile. (A) In the center, the head with streamers around the neck and below, the table for offerings, surrounded by bottles and cans of alcohol. (B) Detail of the neck with streamers around it; in front, a clown doll and, below it, a chuspa, a traditional woven bag, containing banknotes and coca leaves. (C) Old Chilean coins that are no longer legal tender with images of the condor that have been left as offerings (Photos by Andrés Jacques Coper).
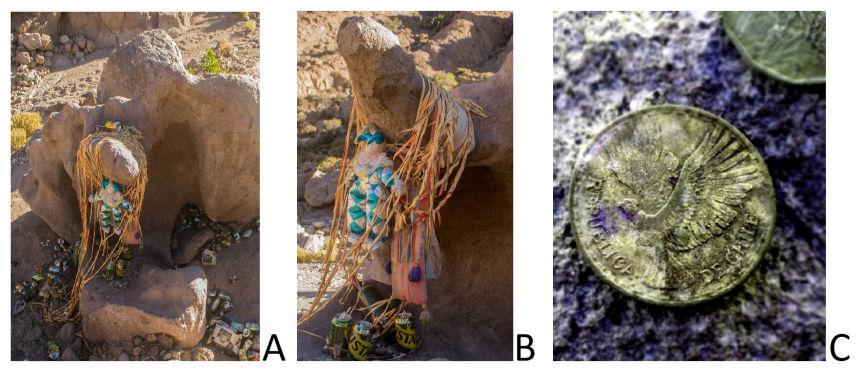

Social importance of the Andean Condor and related institutions Several of Putre's inhabitants considered the condor important in two general senses. First, it represented the legacy of a partly stable and partly diluted indigenous worldview that clings to some memories of the species, a legacy that corresponds to a recent past and whose practice makes less and less sense. In today's social context, the town's inhabitants reacted based on a desire to remember something that has not been faithfully transmitted to them, but that they perceived as relevant to their identity. Particularly for those who considered themselves Aymara, the importance of the Andean Condor was a mixture of personal experience and a diffuse ancestral legacy. From an adaptive point of view, the ancestral cultural manifestations of which the condor is part were difficult for the local population to maintain without a special effort to do so, either because (a) these manifestations have lost their usefulness because productive activities (praxis) have changed and knowledge about the environment in general and the fauna in particular is no longer considered necessary for survival; and (b) these manifestations have been replaced by a different worldview (kosmos), linked to the rapid adoption of Pentecostalism. A minority, always elders ( $>60$ years), understood and reproduced the concept of mallku, but they pointed out that this gradually disappeared in subsequent generations. (Note, quotes are attributed only by ethnicity, gender, and age group because interviewees asked to keep their names confidential):

Mallku is what the higher authority is called. It is used
for the condor because it has its sector where it lives and
moves around in its own way. The condor is the one who
gives orders to everyone. The condor hunts a vicuña and
the others just eat there (Aymara, male, 51-60).

Second, the condor was unequivocally identified as Chile's national symbol. This was not necessarily at odds with the Aymara view because, for Putre's inhabitants, no dichotomy (Aymara- 
Chilean) exists. In a geographical area where national identity is constantly reinforced (Choque 2012), the Andean culture and the Chilean homeland converge in the condor. The condor, as a permanent Chilean social institution, evokes a sense of reinforced identity that does not require direct contact with the bird, merely the idea of its existence.

Unlike in the past, the condor is no longer considered an important threat to local livelihoods (especially by children). In general, there is no conflict now between condors and livestock farmers, a situation that, according to local residents, may reflect the decline in the number of condors. Farmers know how to drive them off and talk about hunting them for their meat, but no longer do so. Less than $10 \%$ of interviewees considered that conservation is exclusively the job of the state, but the prevailing view is that it should be carried out jointly by the state and local residents. In general, local residents did not justify conservation on the grounds of the condor's cultural role in traditional local identity. Most people had a general idea that the condor is related to the Aymara culture or worldview (or to the broader spatial scope of what is "Andean") but, for them, its conservation does not imply revitalizing this culture. This makes it clear that the constant inclusion of the condor in the image of the Andean landscape is not a result of the transmission of TEK about the species, but rather that the condor is valued mainly as a personal reaction based on a diffuse idea. Although some residents may advocate the need to conserve culture to conserve the species or vice versa, there was little clarity about what is to be transmitted. In other words, this argument arose from a desire to conserve the culture, but without being sure what cultural domains and practices would be transmitted through the conservation of the condor.

\section{Transmission of knowledge}

The contemporary Aymara world's cultural conception of the condor is transmitted in three ways: (1) oral tradition: grandparents, understood as any older person without necessarily implying family relationship, are considered the main vectors and guardians of knowledge. Traditional Aymara doctors, Q'olliris, are a special part of this group in that they possess more specific knowledge, particularly about use of the species for medicinal purposes. (2) Experience: direct contact with condors is most likely to happen when looking after livestock because this calls for being aware of their movements, actions, and possible attacks and knowing how to drive them away. (3) Formal education: schoolchildren up to 6th grade (11-12 years old) have classes on the Aymara language and worldview with intercultural teachers who pass on knowledge gathered through their own experience. The condor and its role in the Andean worldview are, therefore, present in the classroom to the extent of the teacher's knowledge about them, but are not a standardized part of the formal syllabus. The teaching instruments used, such as an apron with interchangeable figures of elements of the Andean plateau landscape, therefore, depend on the will of the teacher (Fig. 3).

\section{CHANGING SOCIO-ENVIRONMENTAL CONTEXTS, CHANGING BIOCULTURAL RELATIONS}

Through our ethnographic study, we were able to understand that three main socio-environmental processes have largely influenced the relationship of the local Aymara population with the Andean Condor.

\section{Chileanization}

The territory that is now the Arica y Parinacota Region became part of Chile as a result of the Pacific War (1879-1883). This was followed by a process that sought to achieve the political and cultural homogeneity of the territories annexed by Chile. At the territorial level, existing spaces, rather than new infrastructure, were used for this purpose, accompanied by the presence of Chilean government officials and administrative and military personnel. The process initially took the form of a symbolic Chileanization, with the installation of flags, the use of its blue, red, and white colors in religious festivals, the installation of symbols in schools, and the changing of street names (Choque 2012). An inhabitant of Zapahuira recalled a song about the national emblems learned at school in the first half of the 20th century:

Fig. 3. Apron with elements of the Andean landscape, including condors, used as a teaching aid by an intercultural teacher in Putre in the high Andes of northern Chile (Photo by Andrés Jacques-Coper).

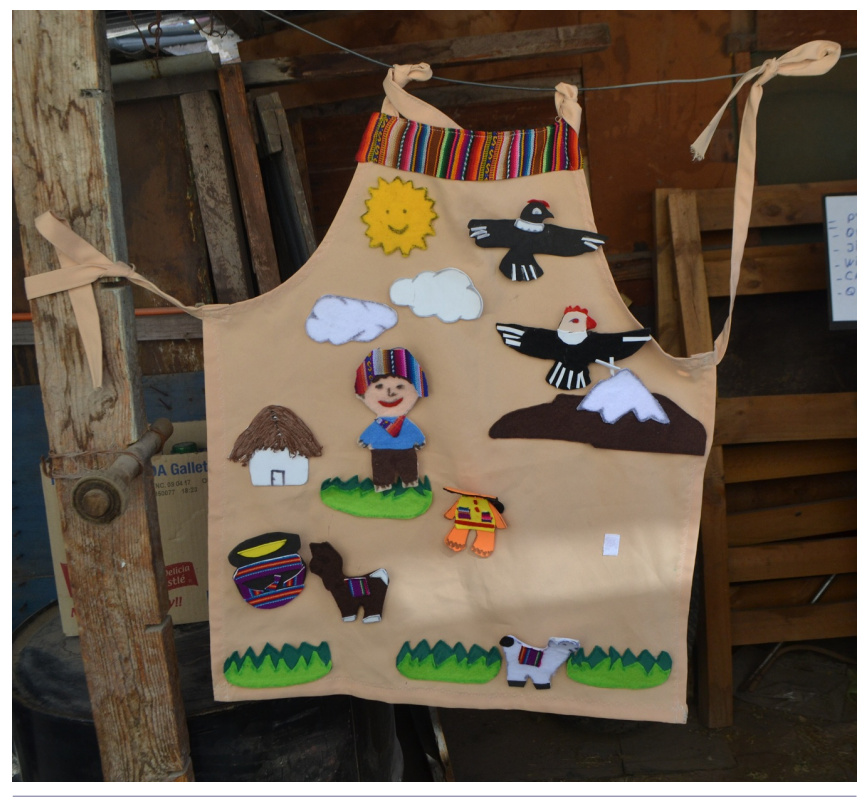

At the summit of the Andes where the condor has its nest, where the guanacos of my beloved nation live, the huemul of our coat of arms is next to the banner, adorning the flag of my beloved nation... My flag has three colors, white, blue, and red are its colors, the wind that moans together with its banner (Aymara, male, 81-90).

Although local residents maintain that being Chilean and Aymara are not incompatible, the evidence indicates that the twofold valuation of the condor as an emblematic figure has resulted in a predominance of the Chilean symbol over its Aymara significance. Cultural domains are related and modification of a symbol's meaning in one domain has an effect in other related domains. Thus, identification of the condor as a symbol of "Chileanness" is accompanied by variations in other domains (for example, language), modifying the underlying concept of the condor, without permitting full coexistence of the Aymara and Chilean perspectives. This process affected local residents, 
influencing their day-to-day culture and the restructuring of local social institutions, as reported by a $Q^{\prime}$ olliri:

On the border, on the other side, they still have the indigenous authorities, the jilakata, the tamani. What happened here when Chileanization arrived is that it was forbidden to speak Aymara, to hold ceremonies. Everything I told you... they killed them, they took them prisoner. That is why people do not speak Aymara and when they want to, it is very difficult. The government has a big debt (Aymara, female, 61-70).

Local residents identified themselves as both Aymara and Chilean, and few were able to say which best represents them. In their view, that definition is unnecessary because the two categories are not mutually exclusive. Chileanization has led to a stigmatization that has had a strong impact on the generations of Aymara who are now adults, particularly in the case of those who live in Arica or have close ties with the city. Numerous accounts indicated a feeling of being looked down on by the city and government policies. This perception begins to fade in younger generations, opening the way to renewed appreciation of the culture of their ancestors. One example of this is the proliferation at the national as well as regional level of Andean music and dance, seen today in carnivals on the coast and in the central zone and covered by the mass media.

\section{Migrations}

Since the middle of the 20th century, the city of Arica has intensified the centralism of what is now the Arica y Parinacota Region. Migration from the countryside to the city and from the mountains to the coast has significantly modified the customs of current urban Aymara, who previously inhabited the valleys, the foothills, and the Andean plateau. The creation of the free port of Arica in 1952 triggered a surge in migration of which there is no sign of a reversal. The move from the rural to the urban world influenced all aspects of migrants' indigenous culture, including their beliefs, knowledge, and production practices (Grebe 1986, Gundermann and González 2008, Quiroz 2012).

The dramatic depopulation of the Andes foothills and mountains as a result of this migratory process has affected the transmission of TEK. In this new urban context, the Aymara could not maintain the traditional agricultural and livestock practices that are where TEK is reproduced and biocultural memory is nurtured (Grebe 1986, Nazarea 2006). In the city, part of the knowledge (corpus) and beliefs (kosmos) can be expressed, but not the practice (praxis). When there is regular, if not permanent, contact between migrant relatives to the coast and local residents, some knowledge is transmitted (and shaped by those who receive it), but not all of it permeates to subsequent generations because it lacks context and weakens. In contrast to the rituals and customs that mark the Aymara calendar in which the community as a whole participates (patron saints' days and the Pachallampe or the ceremony of sowing the potato), wisdom that is only learned through practice, contact, and personal experience requires the land for its transmission (Pretty et al. 2009). Without the experience of caring for livestock or the need to know about traditional medicine, the vitality of this wisdom lacks context because its purpose is to position relationships within the social-ecological system through emotions and to make sense of the world. Greeting the mallku kunturi with respect, bidding farewell without grief to the livestock that the condor has chosen to eat, and using its dried meat to remain young are some of the beliefs that are not part of a basic cultural knowledge that can be transmitted. In the city, these practices become distant fables, without practical sense or personal emotion.

\section{Pentecostalism}

Pentecostalism appeared in the Aymara communities of the foothills and the Andean plateau in the mid-20th century and quickly gained ground in the face of the relative disorganization of the Catholic Church. By that time, Catholic rituals and beliefs had already been deeply syncretized with Aymara traditions. Residents of Putre identified the inhabitants of the Andean plateau as those who maintain the traditions of the Aymara culture, thanks to their distance from the city and the experience of age. Contrary to what was expected, the inhabitants of the Andean plateau settlements, generally elderly people who have spent most or all of their lives there with little contact with urban centers, were emphatic that they do not have a relationship or identification with the condor that is different from what they could have with any other animal. Our ethnography allowed us to identify that the latter is the result of religion.

\section{It is called mallku kunturi in Aymara, that means macho. My father used to say that. My father had the custom of putting wool decorations in the ears of the animals in February, marking them, putting markings in their ears, and there he used to call it mallku kunturi [...]. For me, it's just like any other animal. My father used to perform his ceremonies but I have loved God more. He gives life. He takes care of me here on the hill alone, that's why I do not say anything to the condor (Aymara, female, 81- 90).}

Today, because of their religious convictions, some evangelical Aymara do not practice or at least avoid part of the customs, practices, and traditions that formerly identified the Aymara. As indicated by an inhabitant of Visviri,

The mallku was an intermediary, a being of the hill, it was like praying to the devil. The devil is the son of Jehovah who became rebellious. It's the devil who controls the mallku (Aymara, male, 51-60).

To attribute divine qualities to the condor is contrary to the Evangelical faith.

Other Aymara traditions or customs have also disappeared gradually. This is the case of the manifestations of cultural domains that are not directly viewed by religion as a symbol of a negative practice and persist for some time as a custom, with an underlying change in their meaning. Examples of this include the greeting of condors when they are sighted (now only considered symbols of good luck but, previously, also out of respect for the mallku) and the transmission of narratives that explain hierarchy and relational spheres in the natural complex, including animals and humans. The narratives may still be told, but not to transmit the worldview behind it. As pointed out by Mariz (1994) in her ethnographic work in Brazil, the Pentecostal Christians have a strong aversion to syncretic traditional practices and are critical of the symbols, icons, and rituals associated with folk Catholicism and indigenous religions. 


\section{CONCLUSION AND FINAL REMARKS}

The Andean Condor was and still is an important species for the Aymara people of the high Andes of northern Chile, with personal and symbolic value to some local Aymara residents. However, this research shows that the condor is not currently a species of sufficient importance to be part of a complex TEK with a balance between knowledge, practice, and beliefs. Thus, the Andean Condor can hardly be considered a biocultural keystone species for the Aymara people of northern Chile. Today, the Aymara identity is represented through cultural manifestations such as music, dance, patron saints' festivals, and rituals linked mainly to agriculture. The condor has a limited presence in these cultural expressions. If this trend persists, the few cultural manifestations that involve the species may soon be reduced to an even more diffuse image.

In our study, the condor is recognized by local residents, regardless of their cultural origin, as an important symbol of the Andes. However, its meaning is not shared homogeneously and there is not clarity as to what it is. At the same time, the condor as a Chilean social institution has absorbed the image of a ruling bird that represents national unity. The evidence indicates that historical and ongoing socio-environmental processes in the high Andes have affected the Aymara's TEK associated with the environment and, therefore, the condor. As discussed by Maffi and Dilts (2014) and Pretty et al. (2009), dominant societies and nation state policies affect local TEK, sometimes diluting it and preventing its transmission and, in other cases, supplanting it with modern knowledge. In the north of Chile, this process was cemented by the prohibition on speaking Aymara, thereby impeding the transmission of concepts that are key for the Aymara kosmos and praxis. Without transmission of the concept of mallku in oral tradition and the practice of making offerings, the capacity of new generations to nurture a collective biocultural memory around the condor is undermined.

In short, the three socio-environmental processes described above (Chileanization, migration, and Pentecostalism) have affected the culture differently. Some traditions have survived and, in some cases, have intensified while others, such as the identity associated with the condor, have lost the strength to project themselves into the future with the integrity of the past. For traditions to persist, the cultural domains in which they are present must not clash with pressures from outside the community (for example, policies on the use of fauna) and internal processes of change. Artistic expressions, for example, do not actively interfere with the new religious ethical dynamism, but the condor's use in medicine is not compatible with normative pressures because its hunting is prohibited (SAG 2015) while ritual manifestations are forbidden by the religious currents now present in the area. By contrast, knowledge about the condor's identification, biology, and distribution can be transmitted more easily and is relatively abundant because it is not necessarily in conflict with Pentecostalism or is, in other words, chiefly a matter of knowledge rather than practice and beliefs.

In other studies of suggested biocultural keystone species, such as that of Darwin's Rhea in the Argentine Chaco (Medrano and Rosso 2016) and the Andean Lapwing (Vanellus resplendens; Sarmiento 2016), the links between the social group and the species are reflected with particular clarity in the intensity of use of the species, its persistence in memory and nomenclature (criteria indicated by Garibaldi and Turner 2004 to define a cultural keystone species). These three criteria are extremely scarce in the case of Putre where they appear singly, rather than being generalized across the community. Peroni et al. (2013) reported similar findings for the umbuzeiro tree (Spondias tuberosa) in northeastern Brazil. They report that, although knowledge of the umbuzeiro is extensive among the Faxinalense people, interest in it has decreased as well as the strength of the people's relationship with this culturally and economically important species (Peroni et al. 2013).

The value of our ethnographic study is that, because it was not totally confined to questions about the condor, it provides an insight into daily emotional connection, specific experiences, for example, bird sightings, and the day-to-day expression of other aspects of the culture. Ethnographers can model their interpretation of the local culture and position the species studied in local residents' relational universe. The trend identified in this study is partly in line with the homogenization of biocultural diversity reported by Maffi (2001), Rozzi et al. (2003), and Pretty et al. (2009). As Turner et al. (2000) affirm, this homogenization can be attributed mainly to factors related to rapid economic development, government assimilation policies, and the imposition of coercive educational systems. However, the local Aymara culture retains its own identity, which is today, in fact, reinforced by the dominant and even coercive forces that have eroded it. Outside the local territory, for example, expectations are created and actions taken that are conducive to the culture's revitalization. One example of this is the presence of images of condors in the Arica carnival (Fig. 4) and the murals that have been painted in the foothills, which are urban representations of the Andean worldview and what the Aymara are expected to believe. As indicated above, these artistic and other identityrelated initiatives, e.g., language revitalization projects and the spread and reproduction of murals and books with traditional narratives, many led by the new generations of Aymara, are serving as external sources of biocultural memory. They are key for "restorative memory work" to bridge memory gaps where transmission of the ancestral role of the condor in local culture has failed or was thwarted (sensu Nazarea 2006).

Fig. 4. Dancer representing an Andean Condor at the Carnival with the Force of Sun, Arica, 2017 (Photo by Andrés JacquesCoper).

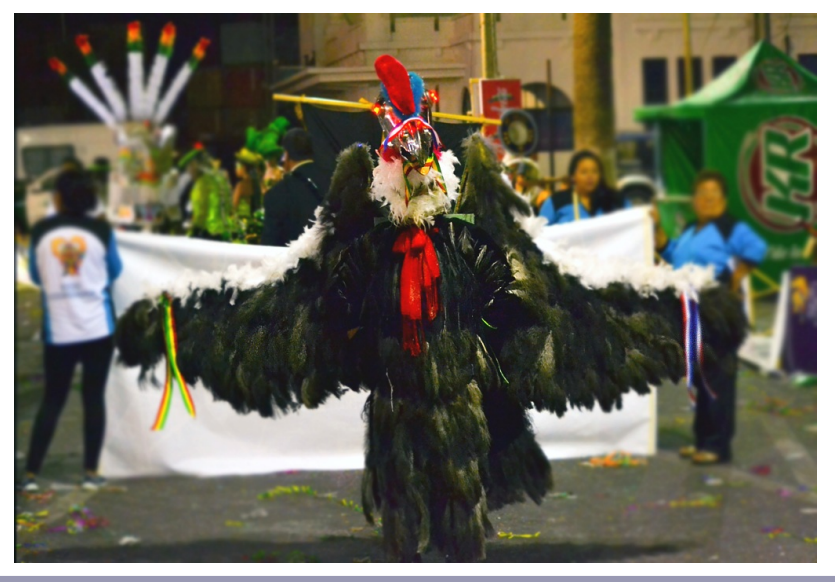


Local cultural manifestations can be understood as a dynamic result in that they have not achieved a definitive form and, indeed, cannot do so. What the Andean Condor means today has changed as compared to the recent past and can do so again in the future. The diagnosis arrived at indicates a complex prognosis. When conservation is proposed, an objective image toward which to work is defined. This can be debatable ecologically but, culturally implies major ethical considerations. Proposals for biocultural conservation must, therefore, be carefully thought out and elicit broad agreement, and it is advisable that the actions to be taken be defined mainly by the community as the body that lives with (and is) the culture. It is necessary to avoid imposing a cultural image that is not what the community wants. In the case of the condor, this implies that at least Aymara, Chilean, and evangelical currents must be taken into account.

Responses to this article can be read online at: http://www.ecologyandsociety.org/issues/responses. $\mathrm{php} / 10939$

\begin{abstract}
Acknowledgments:
Center for Intercultural and Indigenous Research-CIIR (CONICYT/FONDAP/15110006), The Peregrine Fund, F. Hernán Vargas, International Center for Andean Studies (INCAS) of the University of Chile, Servicio País de la Fundación para la Superación de la Pobreza, Familia Troncoso-Chellew, Universidad de Tarapacá (UTA), Corporación Nacional Forestal (CONAF). We also received support from the Center for the Socioeconomic Impact of Environmental Policies (CESIEP,) which is a Millennium Nucleus supported by the Millennium Scientific Initiative of the Chilean Ministry of Economy, Development and Tourism.
\end{abstract}

\section{LITERATURE CITED}

Barthel, S., C. Folke, and J. Colding. 2010. Social-ecological memory in urban gardens: retaining the capacity for management of ecosystem services. Global Environmental Change 20:255-265. https://doi.org/10.1016/j.gloenvcha.2010.01.001

Berkes, F. 2018. Sacred ecology. Fourth edition. Routledge, New York, New York, USA.

Berkes, F., C. Folke, and J. Colding. 2000. Rediscovery of traditional ecological knowledge as adaptive management. Ecological Applications 10(5):1251-1262. http://dx.doi. org/10.2307/2641280

Bernard, H. R. 2011. Research methods in anthropology: qualitative and quantitative approaches. Altamira, Lanham, Maryland, USA

BirdLife International. 2017. Vultur gryphus. The IUCN Red List of Threatened Species 2017. IUCN, Cambridge, UK. http://dx. doi.org/10.2305/IUCN.UK.2017-3.RLTS.T22697641A117360971. $\underline{\text { en }}$

Castro, V. 1986. An approach to the Andean ethnozoology: Toconce. Pages 1-18 in Cultural attitudes to animals including birds, fish and invertebrates. Allen \& Unwin, London, UK.
Castro, V., and J. Rottmann. 2016. Aspectos de la etno-ornitología de la Provincia de El Loa, norte de Chile. Revista Chilena de Ornitología 22(1):64-78.

Choque, C. 2012. "Se van los peruanos... los más testarudos se quedan": la memoria y olvido de la chilenización en el pueblo de Socoroma. Pontificia Universidad Católica de Perú, Lima, Peru.

Corporación Nacional Forestal (CONAF). 1998. Plan de Manejo Reserva Las Vicuñas. Chilean Ministry of Agriculture, Santiago de Chile, Chile.

Costanza, K. K. L., W. H. Livingston, D. M. Kashian, R. A. Slesak, J. C. Tardif, J. P. Dech, A. K. Diamond, J. J. Daigle, D. J. Ranco, J. S. Neptune, et al. 2017. The precarious state of a cultural keystone species: tribal and biological assessments of the role and future of black ash. Journal of Forestry 115(5):435-446. https:// doi.org/10.5849/jof.2016-034R1

del Hoyo, J., A. Elliott, and S. Jordi, editors. 1994. Handbook of the birds of the world. Volume 2. Lynx Ediciones, Barcelona, Spain.

Díaz Araya, A., and M. Tapia Ladino. 2013. Los aymaras del norte de Chile entre los siglos XIX y XX. Un recuento histórico. Atenea 507:181-196. http://dx.doi.org/10.4067/S0718-04622013000100012

Elbroch, L. M., and H. U. Wittmer. 2013. Nuisance ecology: do scavenging condors exact foraging costs on pumas in Patagonia? PLoS ONE 8(1):e53595. https://doi.org/10.1371/journal.pone.0053595

Ellen, R. F. 2006. Local knowledge and management of sago palm (Metroxylon sagu Rottboell) diversity in South Central Seram, Maluku, eastern Indonesia. Journal of Ethnobiology 26 (2):258-298. [online] URL: https://kar.kent.ac.uk/id/eprint/8738

Ferguson-Lees, J., and D. A. Christie. 2001. Raptors of the world. Houghton Mifflin, New York, New York, USA.

Fjeldså, J., and N. Krabbe 1990. Birds of the high Andes. Apollo Books and Zoological Museum, University of Copenhagen, Denmark.

Garibaldi, A., and N. Turner 2004. Cultural keystone species: implications for ecological conservation and restoration. Ecology and Society 9(3):1. https://doi.org/10.5751/ES-00669-090301

González, S. 1999. Interculturalidad y globalización: el caso de los aymaras de Tarapacá. Revista de Ciencias Sociales 9:114-125. [online] URL: https://www.redalyc.org/html/708/70800908/

Gordillo, S. 2000. La magia del cóndor. Ecoval Editorial, Buenos Aires, Argentina.

Gorenflo, L. J., S. Romaine, R. A. Mittermeier, and K. WalkerPainemilla. 2012. Co-occurrence of linguistic and biological diversity in biodiversity hotspots and high biodiversity wilderness areas. Proceedings of the National Academy of Sciences 109 (21):8032-8037. https://doi.org/10.1073/pnas.1117511109

Grebe, M. E. 1983. En torno a los ritos terapéuticos de Isluga. Revista Chungará (10):155-164. [online] URL: https://www.jstor. org/stable/27801773

Grebe, M. E. 1984. Etnozoología andina: concepciones e interacciones del hombre andino con la fauna altiplánica. Estudios Atacameños 7:335-347. https://doi.org/10.22199/ $\underline{\mathrm{S} 07181043.1984 .0007 .00032}$ 
Grebe, M. E. 1986. Migración, identidad y cultura aymara: puntos de vista del actor. Revista Chungará (16-17):205-223.

Grebe, M. E. 1989. El culto a los animales sagrados emblemáticos en la cultura aymara de Chile. Revista Chilena de Antropología (8):35-51. https://doi.org/10.5354/0719-1472.1989.17599

Guerrero, B. 1984. Movimiento pentecostal, corrientes modernistas y sociedad aymara. Cuaderno de Investigación Social $8(57): 1-20$.

Gundermann, H., and H. González. 2008. Pautas de integración regional, migración, movilidad y redes sociales en los pueblos Indígenas de Chile. Revista Universum 23(1):82-115. http://dx.doi. org/10.4067/S0718-23762008000100006

Hernández, J., C. Estades, L. Faúndez, and J. Herreros. 2014. Biodiversidad terrestre de la Región de Arica y Parinacota. Chilean Ministry of the Environment, Santiago de Chile, Chile.

Ibarra, J. T., A. Barreau, F. Massardo, and R. Rozzi. 2012. El cóndor andino: una especie biocultural clave del paisaje sudamericano. Boletín Chileno de Ornitología 18:1-22.

Lambertucci, S. A. 2007. Biología y conservación del cóndor andino (Vultur gryphus) en Argentina. Hornero 22(2):149-158. [online] URL: http://hdl.handle.net/20.500.12110/ hornero v022 n02 p149

Lambertucci, S. A., A. Trejo, S. Di Martino, J. A. Sánchez-Zapata, J. A. Donázar, and F. Hiraldo. 2009. Spatial and temporal patterns in the diet of the Andean Condor: ecological replacement of native fauna by exotic species. Animal Conservation 12:338-345. http://dx.doi.org/10.1111/j.1469-1795.2009.00258.x

Maffi, L. 2005. Linguistic, cultural, and biological diversity. Annual Review of Anthropology 34(1):599-617. https://doi. org/10.1146/annurev.anthro.34.081804.120437

Maffi, L., editor. 2001. On biocultural diversity: linking language, knowledge and the environment. Smithsonian Institution Press, Washington, D.C., USA.

Maffi, L., and O. Dilts. 2014. An introduction to biocultural diversity. Biocultural Diversity Toolkit. [online] URL: http:// terralingua.org/wp-content/uploads/2015/07/tk 1 Primer.pdf

Magaña, E. 2006. Astronomía de algunas poblaciones quechuaaymara del Loa superior, norte de Chile. Boletín Del Museo Chileno de Arte Precolombino 11(2):51-66.

Mariz, C. L. 1994. Coping with poverty: Pentecostals and Christian base communities in Brazil. Temple University Press, Philadelphia, Pennsylvania, USA.

Medrano, M. C., and C. N. Rosso. 2016. El ñandú común (Rhea americana): ¿una especie etnobiológica clave para los qom del Gran Chaco argentino? Revista Chilena de Ornitología 22 (1):51-63.

Millones, L., and R. Mayer. 2012. La fauna sagrada de Huarochirí. Instituto de Estudios Peruanos, Lima, Peru. https://doi. org/10.4000/books.ifea.6527

Montealegre, J. 2007. Identidad y representaciones en un mundo globalizado. Polis 18. [online] URL: http://journals.openedition. org/polis/4085
Nazarea, V. D. 2006. Local knowledge and memory in biodiversity conservation. Annual Review of Anthropology 35:317-335. https://doi.org/10.1146/annurev.anthro.35.081705.123252

Newing, H. 2011. Conducting research in conservation: a social science perspective. Routledge, London, UK.

Ohrens, O., A. Treves, and C. Bonacic. 2016. Relationship between rural depopulation and puma-human conflict in the high Andes of Chile. Environmental Conservation 43(1):24-33. https://doi. org/10.1017/S0376892915000259

Orlove, B. S., and S. B. Brush. 1996. Anthropology and the conservation of biodiversity. Annual Review of Anthropology 25:329-352. https://doi.org/10.1146/annurev.anthro.25.1.329

Oviedo, G., L. Maffi, and P. B. Larsen. 2000. Indigenous and traditional peoples of the world and ecoregion conservation: an integrated approach to conserving the world's biological and cultural diversity. World Wildlife Foundation International and Terralingua, Gland, Switzerland.

Paine, R. T. 1969. A note on trophic complexity and community stability. American Naturalist 103(929):91-93. https://dx.doi. org/10.1086/282586

Palma, M. 1983. El cóndor: dimensión mítica del ave sagrada. América Nuestra, Managua, Nicaragua.

Peroni, N., U. P. de Albuquerque, A. L. de Assis, and E. M. de F. Lins Neto. 2013. The domestication of landscapes and cultural keystone species in a context of community biodiversity management in Brazil. Pages 145-150 in W. Simon de Boef, A. Subedi, N. Peroni, M. Thijssen, and E. O'Keeffe, editors. Community biodiversity management: promoting resilience and the conservation of plant genetic resources. Earthscan, London, UK. https://doi.org/10.4324/9780203130599

Platten, S., and T. Henfrey. 2009. The cultural keystone concept: insights from ecological anthropology. Human Ecology 37 (4):491-500. https://doi.org/10.1007/s10745-009-9237-2

Posey, D. A. 1999. Cultural and spiritual values of biodiversity. Intermediate Technology, London, UK. https://doi. org/10.3362/9781780445434

Pretty, J., B. Adams, F. Berkes, S. F. de Athayde, N. Dudley, E. Hunn, L. Maffi, K. Milton, D. Rapport, P. Robbins, et al. 2009. The intersections of biological diversity and cultural diversity: towards integration. Conservation and Society 7(2):100-112. https://doi.org/10.4103/0972-4923.58642

Quiroz, D. 2012. De Migrantes cordilleranos a pobladores urbanos. Fondo Nacional de Desarrollo Cultural y las Artes, Santiago de Chile, Chile.

Rodríguez, J. P., and F. Rojas-Suárez. 2008. Libro Rojo de la fauna venezolana. Third edition. Provita and Shell Venezuela, S.A, Caracas, Venezuela.

Rozzi, R., F. Massardo, J. Silander, C. Anderson, and A. Marín. 2003. Conservación biocultural y ética ambiental en el extremo austral de América: oportunidades y dificultades para el bienestar ecosocial. Pages 57-85 in E. Figueroa and J. A. Simonetti, editors. Globalización y Biodiversidad: oportunidades y desafios para la sociedad chilena. Editorial Universitaria, Santiago de Chile, Chile. 
Sarmiento, F. 2016. Identidad, imaginarios e idealidad: entendiendo el paisaje biocultural andino a través del icónico tero serrano (Vanellus resplendens). Revista Chilena de Ornitología 22 (1):38-50.

Servicio Agrícola y Ganadero (SAG). 2015. La Ley de Caza y su Reglamento. Sixth edition. Ministerio de Agricultura, Gobierno de Chile, Santiago, Chile. [online] URL: http://www.sag.cl/sites/ default/files/ley de caza y su reglamento 2015.pdf

Toledo, V., and N. Barrera-Bassols. 2008. La memoria biocultural. La importancia ecológica de las sabidurías tradicionales. Icaria Editorial, Barcelona, Spain.

Turner, N. J., M. B. Ignace, and R. Ignace. 2000. Traditional ecological knowledge and wisdom of aboriginal peoples in British Columbia. Ecological Applications 10(5):1275-1287. https://doi. org/10.2307/2641283

Uprety, Y., H. Asselin, and Y. Bergeron. 2017. Preserving ecosystem services on indigenous territory through restoration and management of a cultural keystone species. Forests 8(6):194. https://doi.org/10.3390/f8060194

Valenzuela, D., C. M. Santoro, J. M. Capriles, M. J. Quinteros, R. Peredo, E. M. Gayo, I. Montt, and M. Sepúlveda. 2015. Consumption of animals beyond diet in the Atacama Desert, northern Chile (13,000-410 BP): comparing rock art motifs and archaeofaunal records. Journal of Anthropological Archaeology 40:250-265. https://doi.org/10.1016/j.jaa.2015.09.004

van Kessel, J. 1985. Los aymaras contemporáneos de Chile (1879-1985); su historia social. Cuaderno de Investigación Social 16(57):33.

Vargas-Clavijo, M., and E. M. Costa Neto. 2008. Los limpiadores de los cielos: factos y folclor de los zopilotes, aves dueñas del imaginario latinoamericano. Universidade Estadual de Feira de Santana, Feira de Santana, Brazil. 